\title{
A new lichen species from the Heritage Range, Ellsworth Mountains, Antarctica
}

\author{
Dag Olav Øvstedal ${ }^{1,3}$ and Carlos Ernesto Gonçalves Reynaud Schaefer ${ }^{2}$
}

Received: 3.10.2012; accepted: 11.04.2013

ABSTRACT - (A new lichen species from the Heritage Range, Ellsworth Mountains, Antarctica). Opegrapha edsonii, with soralia and norstictic acid is described.

Key words: Antarctica, norstictic acid, Opegrapha edsonii

RESUMO - (Uma nova espécie de líquen de Heritage Range, Montanhas Ellsworth, Antártica). Uma nova espécie de liquen, com soralia e ácido norstíctico, Opegrapha edsonii é descrita, ocorrendo nas Montanhas Ellsworth, Antártica continental. Palavras-chave: Antártica, ácido norstíctico, Opegrapha edsonii

\section{Introduction}

The terrestrial biota of the Antarctica comprises almost exclusively lower organism, and among these, lichens are by far the most dominant. New knowledge has revealed a higher diversity of lichen species than previously known (Ruprecht et al. 2012), and the total number for the Antarctic and South Georgia now well exceeds 500 (Øvstedal \& Lewis Smith 2011, Øvstedal unpublished data).

A soil and permafrost field study in the Ellsworth Mountains in the summer 2012 included the collection of some lichens growing on cryoturbic soils from ice free areas of the Union Glacier Region in the southern Heritage Range. The Heritage Range forms the southern part of the Ellsworth Mountain system, consisting of scattered ridges and peaks of moderate height, escarpments, hills and nunataks, the various units of relief set off by numerous intervening glaciers, such as the Union Glacier (figure 1). Lichens were sampled on two polygonal soils, both on felsenmeer of Crashsite quartzite, one at $754 \mathrm{~m}$ and one at $785 \mathrm{~m}$ altitude.

The collection comprises both saxicolous and terricolous lichens. Only the saxicolous ones are treated here. Among these was an undescribed species, which is described below.

\section{Material and methods}

The specimens are deposited in BG. Anatomy and morphology were studied using a Zeiss Stemi 2000C microscope, and a Zeiss Axiolab compound microscope. Chemical constituents were identified by thin layer chromatography (Elix \& Ernst-Russell 1993).

Soil material associated with the lichens were studied by routine chemical analyses $(\mathrm{pH}$, available $\mathrm{P}$, exchangeable $\mathrm{Ca}^{2+}, \mathrm{Mg}^{2+}, \mathrm{K}^{+}, \mathrm{Al}^{3+}$, $\mathrm{H}+\mathrm{Al}$, and extractable $\mathrm{Pb}$ and $\mathrm{Cu}$ ) and textural analyses (granulometry), all carried out by standard international procedures (Kuo 1996, EMBRAPA 1997). Total organic carbon was determined according to Yoemans \& Bremner (1988).

\section{Results and Discussion}

Opegrapha edsonii Øvstedal \& C. Schaefer sp. nov. Figure 2

Opegrapha gyrocarpa similis, sed soredia minoribus et acidum norsticticum continens. Apothecia et pycnidia non vidi.

Type: Antartica. Antarctic Peninsula: Ellsworth Mountains, Heritage group, Edson Hill, $79^{\circ} 50^{\prime} \mathrm{S}$ and 83³9'W, 10-I-2012, C. Schaefer 2012-05 (holotypus $\mathrm{BG})$.

1. University Museum, P.O. Box 7803, N-5020 Bergen, Norway

2. Soil Science Department, Viçosa Federal University, 36570-000 Viçosa, MG, Brazil

3. Corresponding author: dag.ovstedal@um.uib.no 
Thallus crustose, ca. $1 \times 0.4 \mathrm{~cm}$, up to $1.5 \mathrm{~mm}$ thick, sorediate, dark brown to brown-grey, strongly rimose to areolate, areolae convex, 0.2-0.4 $\mathrm{mm}$ diam., crowded, scabrid, UV-. No prothallus seen. Photobiont Trentepohlia, cells in clusters, 4-5 $\mu \mathrm{m}$ diam., similar to those in W Norwegian specimens of $O$. gyrocarpa (several specimens in BG examined). Soralia pink, when eroded orange (carotenoids in Trentepohlia), up to $0.4 \mathrm{~mm}$ diam., with irregular outline, crater-formed to flat. Soredia coarse, $17.1 \pm 2.03 \mu \mathrm{m}(\mathrm{n}=20)$, conglutinated into consoredia up to ca. $70 \mu \mathrm{m}$ wide. No hyphae projecting from soredia. No apothecia or pycnidia seen.

Chemistry: norstictic acid.

Habitat: mostly overgrowing a sterile white crust (with Carbonea vorticosa (Flörke) Hertel as parasymbiont) on rock.

The specimen is similar to Opegrapha gyrocarpa Flotow, found in Europe, Asia, Macaronesia and North America (Smith et al. 2009), but differs in chemistry, having smaller soredia and distinct different ecology. Opegrapha gyrocarpa grows mainly under rock overhangs, but also rarely on bark (Tønsberg 1992). It has discrete soredia, but the soralia are larger, $24.5 \pm 2.04 \mu \mathrm{m}$ (several Norwegian specimens in BG studied). In addition, O. gyrocarpa contains gyrophoric and \pm schizopeltic acids. Generally the thallus is smooth and thin, not rough and thick as in the present species. Norstictic acid is found in the paleotropic species $O$. semiatra Müll. Arg. and O. mozambica Vain. (Ertz 2009), both of which are non-sorediate species and very different from

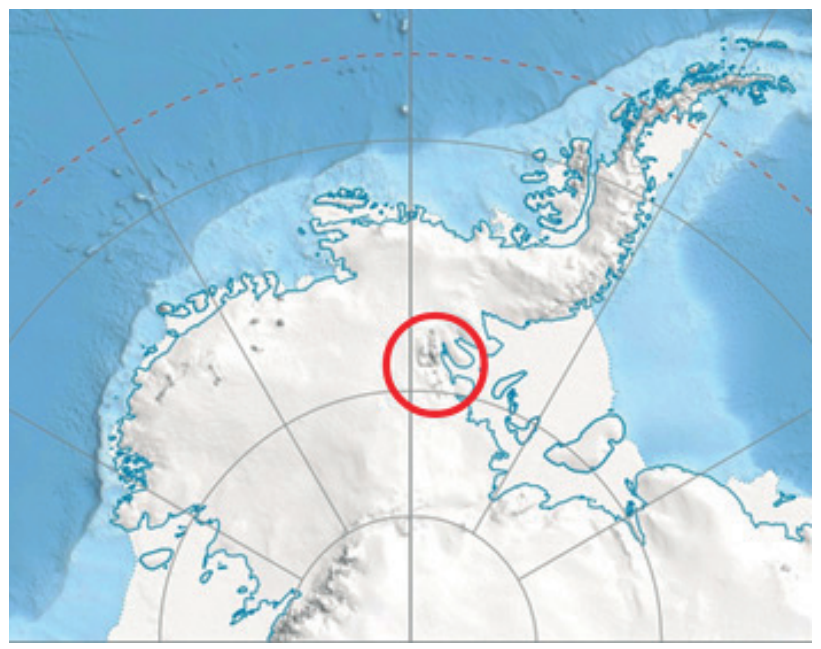

Figure 1. Map of Antarctic peninsula with location of Ellsworth Mountains marked.
O. edsonii. Other taxa with Trentepohlia as photobiont recorded from the Antarctic include Cystocoleus aff. ebeneus (Dillw.) Twaites (Øvstedal \& Lewis Smith 2001) and Porina aenea (Wallr.) Zahlbr. (Øvstedal \& Lewis Smith 2004). A number of Opegrapha species are known from Argentina (Redinger 1940), but they are all corticolous and non-sorediate, with no species similar to $O$. edsonii known (S. Calvelo unpublished data).

The following lichens were collected from the same locality: Bacidia subcoprodes Olech \& Czarnota, Buellia evanescens Darb., B. cf. grisea C.W. Dodge \& G.E. Baker, B. cf. lignoides Filson, Lecanora polytropa (Hoffm.) Rabenh., L. aff. orosthea (Ach.) Ach., Carbonea vorticosa (Flörke) Hertel, Pseudephebe minuscula (Nyl. ex Arnold) Brodo \& D. Hawksw. and Umbilicaria decussata (Vill.) Zahlbr.

The soils had permafrost at between $10-15 \mathrm{~cm}$ depth, and showed cryoturbic features, though not very well developed. Lichens were found growing on sheltered, loose fragments of rock and on soil in the middle of the sorted polygons of north-western facing slopes. Liquid water was present within the polygons.

The soils had dry and ice-cemented permafrost, with turbic microstructure. Location and soil temperatures at $10^{\text {th }}$ January 2012: site 1 (UTM $0469778 / 1143176$, alt. $754 \mathrm{~m})$; air temperature $4.6^{\circ} \mathrm{C}$; $5 \mathrm{~cm}:-0.6{ }^{\circ} \mathrm{C}$; $10 \mathrm{~cm}$ : $-2.6{ }^{\circ} \mathrm{C} ; 15 \mathrm{~cm}-1.9{ }^{\circ} \mathrm{C}$; site 2 (UTM 0469922/1143193, alt. $785 \mathrm{~m}$ ); air temperature $3.3{ }^{\circ} \mathrm{C}, 5 \mathrm{~cm}: 2.3{ }^{\circ} \mathrm{C} ; 10 \mathrm{~cm}:-0.8{ }^{\circ} \mathrm{C} ; 15 \mathrm{~cm}:-1.9^{\circ} \mathrm{C}$.

The climate in the Heritage range is typical of the low Plateau of continental Antarctica (e.g. Byrd Station), and average air temperature at the Union Glacier is around -12 to $-35^{\circ} \mathrm{C}$.

Surface temperatures above zero last for a few hours a day, and during for less than 30 days during the summer. It is very cold year-round, with approx. -12 to $-35{ }^{\circ} \mathrm{C}$ monthly averages, with decreasing temperatures decreasing with altitude. In the summer, clear skies, calm air and little precipitation is common; other phenomena are the strong karabatics, occasional fogs and low clouds from the Ronne ice shelf (King \& Turner 1997).

Based on soil characterization, all sites have alkaline pHs and salt accumulation on the lee side of rock fragments; salts are usually gypsum $\left(\mathrm{CaSO}_{4} \cdot \mathrm{nH}_{2} \mathrm{O}\right)$ and typical of Ellsworth Polar desert soils; the amounts of available $P$ is surprisingly high by polar desert standards, and with very low amounts of organic carbon (table 1), corroborating the extremely low 


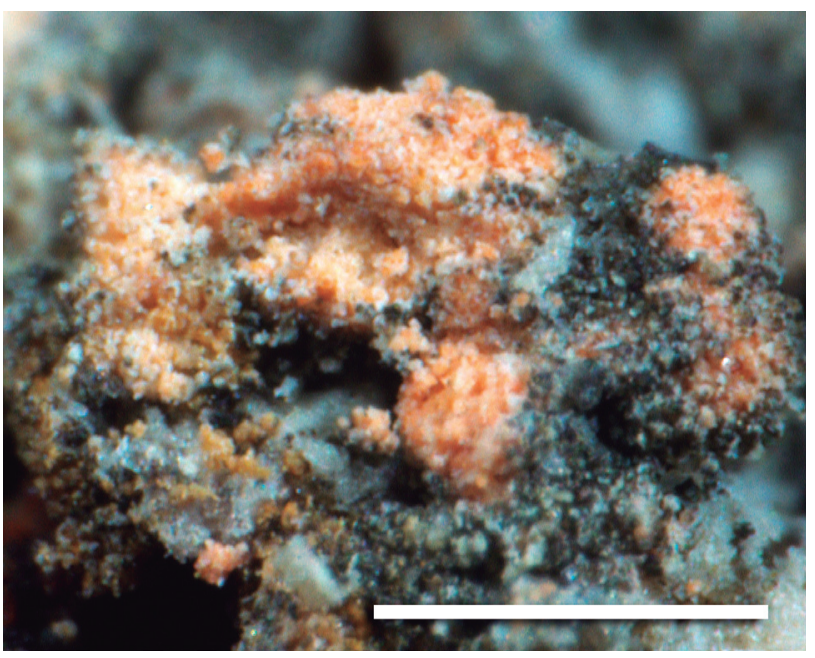

Figure 2. Opegrapha edsonii. Holotype. Scale bar $=1 \mathrm{~mm}$.

biomass. The amount of selected heavy metals $(\mathrm{Pb}$ and, $\mathrm{Cu}$ ) are within the range of polar desert soils. The relative concentration of exchangeable cations ( $\mathrm{Ca}, \mathrm{Na}, \mathrm{Mg}$ and, $\mathrm{K}$ ) in nutrient-poor quartzites can be attributed to salt sprays from distant marine sources, concentrated by long term deposition and the absence of leaching.

These extremophilous lichens are present on nutrient-poor substrates (quartzites) and associated with salt-affected soils from the Antarctic Polar deserts. They have only been observed on sheltered sites where liquid water was apparent, and mostly on northern or north-western facing slopes.

\section{Ackowledgements}

J. Berge and B. Helle, Bergen, are thanked for assistance with illustrations. Dr. Susana Calvelo, Bariloche, is thanked for information. Prof. Carlos Schaefer thanks CAPES (Brazilian Ministry of Education) for granting and funding a sabbatical leave at SPRI-Cambridge. Field work in the Ellsworth Mountains was supported by INCT da CriosferaCNPq/Brazilian Antartic Program.

\section{Literature cited}

Elix, J.A. \& Ernst-Russell, K.-D. 1993. A catalogue of standardized thin layer chromatographic data and biosynthetic relationships for lichen substances. 2.ed. Australian National University, Canberra. 
EMBRAPA. 1997. Manual de métodos de análise de solo, Empresa Brasileira de Pesquisa Agropecuaria. Rio de Janeiro.

Ertz, D. 2009. Revision of the cortociolous Opegrapha species from the Paleotropics. Bibliotheca Lichenologica 102: 1-176.

King, J.C. \& Turner, J. 1997. Antarctic Meteorology and Climatology. Cambridge University Press, Cambridge.

Kuo, S. 1996. Phosphorus. In: D.L. Sparks, A.L. Page, P.A. Helmke, R.H. Loeppert, P.N. Soltanpour, M.A. Tabatabai, C.T. Johnston \& M.E. Summer (eds.). Methods of soil analysis: chemical methods. Part 3. Soil Science Society of America, Madison, pp. 869-919.

Øvstedal, D.O. \& Lewis Smith, R.I. 2001. Lichens of Antarctica and South Georgia. A guide to their identification and ecology. Cambridge University Press, Cambridge.

Øvstedal, D.O. \& Lewis Smith, R.I. 2004. Further additions to the lichen flora of Antarctica and South Georgia. Nova Hedwigia 88: 157-168.
Øvstedal, D.O. \& Lewis Smith, R.I. 2011. Four additional lichens from the Antarctic and South Georgia, including a new Leciophysma species. Folia Cryptog. Estonica 48: 65-68

Ruprecht, U., Lumbsch, H.T., Brunauer, G., Allan, T.G. \& Türk, R. 2012. Insights into the Diversity of Lecanoraceae (Lecanorales, Ascomycota) in continental Antarctica (Ross sea region). Nova Hedwigia 94: 287-306.

Smith, C.W., Aptroot, A., Coppins, B.J., Fletcher, A., Gilbert, O.L., James, P.W., \& Wolseley, P.A. 2009. The lichens of Great Britain and Ireland. British Lichen Society, London.

Tønsberg, T. 1992. The sorediate and isidiate, corticolous, crustose lichens in Norway. Sommerfeltia 14: 1-331.

Redinger, K. 1840. Die Graphidineen der ersten Regnell'schen Expedition nach Brasilien 1892-94. IV. Opegrapha. Arkiv för Botanik 29A: 1-52.

Yoemans, J.C. \& Bremner, J.M. 1988. A rapid and precise method for routine determination of organic carbon in soil. Communications on Soil Science and Plant Analyses 19: 1467-1476. 